\title{
FALASIFA
}

Strategi Power Edukatif Kiai Pada Pengembangkan

\section{STRATEGI POWER EDUKATIF KIAI PADA PENGEMBANGKAN IKLIM ORGANISASI INKLUSIF DI PESANTREN AL-QODIRI DAN PESANTREN NURUL ISLAM JEMBER}

\author{
Moh.Dasuki \\ Mahasiswa Pasca Sarjana Program Doktor IAIN Jember \\ Email: dasukiaufklarung@yahoo.com
}

\begin{abstract}
The educative politics of the kiai with their power patterns are important in creating and creating an inclusive generation in pesantren. Therefore the kiai is the main figure in Developing the Organizational Climate. the purpose of this research is to find the Kiai's Educational Power Strategy in Developing an Inclusive Organizational Climate in Al-Qodiri Islamic Boarding School and Islamic Boarding School Nurul Jember. This type of research is qualitative with a case study approach designed with multi site. Data analysis used Miles and Huberman's Interactive Analysis Model which was carried out in two stages, namely single site analysis and cross-site analysis, while data wetness used source triangulation and member checks. The results of this study are First, the power of kiai is the identity of democratic and charismatic leadership, second, the source of power from the attitudes and principles of leadership, third, the basic power base of the family, education, moderate environment, cultural and structural activities of religious organizations, fourth, power capital. intellectual, emotional and spiritual, while the model consists of refrent power, persuasive power, power given by society, advice power, appreciative power and double connection power, fifth, power tactics through appreciation, facilitation, sharing and motivation while the control media uses monthly friendship forums and weekly gathering with close family and subordinates.
\end{abstract}

Keywords: Power, Kiai, Inclusive Organizational Climate

\begin{abstract}
Abstrak
Politik edukatif kiai dengan pola powernya adalah hal penting dalam menciptakan dan mencetak generasi yang inklusif di pesantren. Oleh karena itu kiai sosok utama Pada Pengembangkan Iklim Organisasi tersebut. tujuan penelitian ini untuk Untuk menemukan Strategi Power Edukatif Kiai Pada Pengembangkan Iklim Organisasi Inklusif Di Pesantren Al-Qodiri Dan Pesantren Nurul Islam Jember.Jenis penelitian Kualitatif dengan pendekatan studi kasus yang dirancang dengan multi situs. Analisis data menggunakan Model Analisis Interaktif Miles dan Huberman yang dilakukan dua tahap yaitu analisis situs tunggal dan lintas situs sedangkan kebasahan data menggunakan trianggulasi sumber dan member cek.

Hasil penelitian ini adalah Pertama, Kekuasaaan kiai merupakan jati diri kepemimpinan demokratis dan kharismatik, kedua, Sumber kekuasaan dari sikap dan prinsip kepemimpinannya,ketiga, Basis dasar kekuasaan dari keluarga,pendidikan, lingkungan moderat, aktivitas kutural dan struktural organisasi kegamaan,keempat, Modal kekuasaan intlektual, emosional dan spritual, sedangkan Modelnya terdiri refrent power, persuasif power, power given by society, advice power, apresiatif power dan Doble conection power,kelima, taktik kekuasaan melalui apresiasi, fasilitasi, sharing dan motivasi sedangkan media kontrolnya menggunakan forum silaturrahim bulanan dan silaturrahim mingguan bersama keluarga dekat dan bawahannya.
\end{abstract}

Kata Kunci: Power, Kiai, Iklim Organisasi Inklusif 


\section{Moh.Dasuki}

\section{PENDAHULUAN}

Kiai selain sebagai seorang leader,kiai juga sebagai seorang manajer.maka wajar bila dinamika kehidupan pesantren mutlak tergantung pada figur kiai. ${ }^{1}$ Adalah KH.Ach.Muzakky Syah sebagai Kiai kharismatik Jember yang telah menorehkan prestasi kepemimpinanya dalam mengantarkan pesantren Al-Qidori mengalami beberapa transformasi kelembagaan yang cukup pesat. Beberapa pendidikan yang telah dirintisnya dimulai dari tingkat lembaga anak-anak hinggi perguruan tinggi.Ketokohan KH.Muzakki Syah dan perkembangan Jama'ah Manaqib hingga ketingkat Regional menjadi berkah tersendiri bagi ekpansi kelembagaan dan memperkenalkan Pesantren Al-Qodiri kemata Dunia.sampai detik ini ada sekitar 31 lembaga atau Pesantren yang bergabung dengan pesantren pusat. Lembaga-lembaga ini milik Jama'ah Manaqib. ${ }^{2}$

Perkembangan baik pesantren dan jamaah dzikir manaqibnya dipengaruhi oleh Pola kepemimpinan KH.Ach.Muzakky Syah yang praktekkannya. Pola beliau dalam memimpin menggunakan kepemimpinan spritual karena selalu mengedepankan proses-proses uswah hasanah melalui amalan-amalan seperti dzikir, doa, jama'ah dan manaqib.Selain mengedepankan spritualitas dalam memimpin, KH.Ach.Muzakky Syah mengamalkan kepemimpinan demokratis sebab dalam mempimpin lembaga yang diasuhnya, beliu selalu mengedepankan pola share leadership yaitu membagi kepemimpinan pesantren dengan membentuk yayasan Al-Qodiri. Kepemimpinan dirinya dipengaruhi oleh faktor keyakinan yang kuat, Istiqomah,Asasul Khomsah, cinta dan kesabaran,serta faktor keistimewaan dan karomah. Melalui model kepemimpinan tersebut KH.Ach.Muzakky Syah tidak hanya berpengaruh pada santri-santrinya namun kepada masyarakat secara luas. ${ }^{3}$

Modal politik pendidikan yang dimainkan oleh KH.Ach.Muzakky Syah tersebut membentuk jalinan dari setiap elemen baik santri dan masyarakat yang berada dibawah kendali dengan politik dan power yang kuat. KH.Ach.Muzakky Syah telah membentuk iklim keagamaan yang inklusif dan keilmuan pesantren melalui lembaga-lambaga yang telah dibentuknya. kekuatan Manaqib KH.Ach.Muzakky Syah membuat pengaruh kultur beliau begitu kuat di

\footnotetext{
${ }^{1}$ Mujamil Qomar, Pesantren dari Tarnsformasi Metodologi Menuju Demokratisasii Institusi (Jakarta: Erlangga, 2004),Hal 32

${ }^{2}$ Dokumentasi PP.Al-Qodiri

${ }^{3}$ Walid, Napak tilas kepemimpinan KH.Ach.Muzakky Syah, (Yogyakarta : Absolut Media, 2010),Hal, 69-80

114| Falasifa, Vol. 11 Nomor 2 September 2020
} 
masyarakat arus bawah, sehingga beliau selalu menjaga kenyamanan masyarakat yang datang kepadanya. ${ }^{4}$

Bila KH.Ach.Muzakky Syah dikenal sebagai tokoh spritual dan pengaruh kultur kegamaannya cukup kuat pada masyarakat arus bawah, KH. Muhyidin Abdusshomad adalah tokoh yang tidak kalah pentingnya dan pengaruhnya cukup kuat di Kabupaten Jember. KH. Muhyidin Abdusshomad dikenal sebagai tokoh berpengaruh di struktural NU Jember beliau juga sebagi tokoh intlektual yang memiliki banyak karya. ${ }^{5}$

Melalui kepemimpinan dengan pengaruh KH. Muhyidin Abdusshomad yang ia ciptakan, sampai saat ini Pesantren Nuris Mengalami perkembangan yang cukup pesat. ${ }^{6}$ KH. Muhyidin Abdusshomad membentuk iklim organisasi pesantren dan pembelajaran inovatif dengan banyaknya program-program unggulan yang ada. Distribusi kekuasaan disalurkan pada putraputra beliau yang telah ditempa dibeberapa pesantren dan perguruan tinggi baik didalam negeri maupun diluar Negeri.

Dari gambaran singkat tersebut Pesantren Al-Qodiri dengan KH.Ach.Muzakky syah selaku tokoh spritual yang memiliki Jamah Manaqib ribuan jumlahnya beliau juga dikenal pemimpin yang demokratis. KH. Abdusshomadpun juga memiliki pesona yang berbeda bila dibandingkan dengan sosok KH.Ach.Muzakky syah. KH. Muhyidin Abdusshomad tokoh intlektual NU Jember yang tidak memiliki manaqib namun beliau bergerak secara struktural di dalam Jam'iyah NU. Kedua tokoh tersebut merupakan aset besar bangsa yang memiliki potensi dan model tersendiri dalam mengayomi santri dan masyarakatnya, yang satu bergerak pada wilayah struktur dan yang satunya selaku tokoh kultural NU Kharismatik. Baik KH.Ach.Muzakky dan KH. Muhyidin Abdusshomad memiliki prestasi pada bidangnya masingmasing, beliau berdua telah membentuk iklim organisasi dan pembelajaran yang produktif mengantarkan pesantren yang diasuhnya menjadi pesantren yang kompetitif serta inklusif ditengah persaingan zaman yang begitu sengit. Beliau menggunakan politik serta pengaruhnya (Power) untuk menciptakan tradisi berorganisasi yang konstruktif serta inklusif, mengelola dan memimpin organisasi yang disebut pesantren dengan skill dan kemampuan leadershipnya.

\footnotetext{
${ }^{4}$ KH.Ach.Muzakky Syah bergerak di masyarakat arus bawah dengan modal kultur yang berkembang di masyarakat Nahdiyyin yaitu manaqib syeh abdul Qodir Al-Jailani.

${ }^{5}$ Dokumentasi PP.Nuris Antirogo Jember

${ }^{6}$ Dokumentasi PP.Nuris Antirogo Jember
} 


\section{Moh.Dasuki}

Belakangan banyak pesantren-pesantren besar yang terindikasi telah terpapar radikalisme, bahkan lebih dari itu, BNPT menyebut bahwa banyak pesantren terlibat aktif menyebarkan paham Radikalisme.Setidaknya pada tahun 2016 ada sekitar 20 Pesantren yang dirilis menyebarkan paham radikalisme salah satunya Pesantren Al Faruq di Jalan Danau Toba Jember Jawa Timur yang Ketuanya bernama Amin Rojab. Dan pada tahun 2019 menyusut menjadi 16 pesantren sebagai temuan BNPT.Jelas pesantren yang terindikasi radikal tersebut secara organisasi lebih kepada organisasi eksklusif. Bukan tidak mungkin jumlah itu akan bertambah banyak. Maka cukup penting membaca secara kritis profil Kiai dalam menjalankan roda organosasinya di pesantren.

Disinilah sosok KH.Ach.Muzakky syah dan KH. Muhyidin Abdusshomad menampilkan diri sebagai manajer dalam mengembangkan iklim organisasi inklusif baik pada santri dan masyarakat luas melalui gaya politik organisasi yang digunakannya. Untuk itu menarik bila KH.Ach.Muzakky syah dan KH. Muhyidin Abdusshomad menjadi kajian dengan fokus strategi power edukatif kiai pada pengembangkan Iklim organisasi Inklusif Di pesantren Al-Qodiri dan pesantren Nurul Islam Jember.

\section{METODE PENELITIAN}

Jenis peneletian ini kualitatif dengan pendeatan studi kasus yang dirancang menggunakan multi situs. Informan dipilih menggunakan menggunakan tehnik purpossive sampling.untuk Teknik Pengumpulan Data menggunakan Wawancara mendalam (indepth interview), Pengamatan peran serta (participant observation), dan Dokumentasi. Analisis Data dilakukan dua tahap, yaitu: Analisis data Situs Tunggal dan Analisis data lintas Situs (cross case analysis) sedangkan menggunakan kebsahan data menggunakan trianggulasi sumber dan member cek.

\section{PEMBAHASAN}

\section{Konsep kekuasaan}

\section{a. Hakekat Kekuasaan (Power)}

Bila dicermati dari kacamata organisasi kekuasaan memang tidak bisa dipisahkan dari mereka yang memegang kekuasaan. Kekuasaan dan pengaruh; melaksankan kepemimpinan dan menjalankan politik, kemampuan potensial pemimpin untuk 


\section{Strategi Power Edukatif Kiai Pada Pengembangkan Iklim Organisasi}

mempengaruhi orang lain. Kepimimpinan merupakan seperangkat pross pengaruh interpersonal. $^{7}$

Fremont dan Rosenzweig menyatakan bahwa "Kekuasaan adalah kemampuan melaksanakan atau mempengaruhi sesuatu”. Ia mengandung arti kesanggupan mempengaruhi orang lain. ${ }^{8}$ hal senada juga disampikan oleh Gibson bahwa "Ability to get others to do what one wants them to do."

Sejalan dengan pendapat di atas Robbins, mendefinisikan kekuasaan mengacu kepada kapasitas yang dimuiliki A untuk mempengaruhi perilkau B, sehingga B bertindak sesuai dengan keinginan A. Definisi tersebut mengisyaratkan suatu potensi yang tidak perlu diaktualisasikan agar menjadi efektif dan suatu hubungan ketergantungan. Kekuasaan bisa ada tanpa dipergunakan, oleh karena itu kekuasaan adalah adalah suatu kapasitas atau potensi. Aspek yang terpenting dari kekuasaan adalah bahwa kekuasaan merupakan suatu fungsi dari ketergantungan. ${ }^{9}$ Power yang dimaksud di sini adalah kemampuan (ability) yang terpisah dari wewenang atau kendali formal terhadap sumberdaya dan reward untuk mempengaruhi orang lain. ${ }^{10}$

\section{b. Perspektif Kekuasaan}

Dalam interaksi tersebut terdapat orang atau sekelompok orang yang menyebabkan orang atau kelompok lain melakukan sesuatu yang diinginkannya. Kemampuan tersebut disebut kekuasaan. "Power as the ability to get an individual or group to do somethin to get the person or group to change in some way". ". Sedangkan menurut Gibson et.al, kekuasaan adalah kemampuan untuk membuat orang lain melakukan apa yang diinginkan oleh pihak lainnya. ${ }^{12}$

Dalam organisasi, Kekuasaan dirancang secara formal (legitimate power) sering disebut sebagai authority. "Authority and is a source of power or is the right to manipulate or change others ${ }^{\prime 13}$. Lebih lanjut dikemukakan oleh Barnard (dalam Luthans, 1986) bahwa "authority as the character of a communication (order) in a formal organization by virtues

\footnotetext{
${ }^{7}$ Luthan, Fred, Organizational Behavior ((Ninth edition), Mc. Graw- Hill, Boston,2002), hal.433

${ }^{8}$ Fremonth E. Kast and Rosenzweig, Organisasi dan Manajemen: Alih Bahasa. Jakarta: Bumi Aksara,2002),hal.517

${ }^{9}$ Stephen Robbins, Perilaku Organisasi: (Terjemahan: Edisi Kedelapan: Jilid I. Jakarta: Prenhallindo,2001),hal.50

${ }^{10}$ Pfeffer, M. The Art to maintenance Human Resources. New York:Mc. Graw-Hill Company, 1996),hal.226

${ }^{11}$ Fred Luthans, Organizational Behavior, New York: McGraw-Hill,1986),hal.447

${ }^{12}$ Gibson, Invancevich dan Donnelly, Jr,. Organisasi: Perilaku, Struktur, Proses, alih bahasa oleh Nunuk Adiarni, (Jakarta: Binarupa Aksara,2001),hal.480

${ }^{13}$ Fred Luthans, Organizational Behavior..hal.448
} 
of which it is accepted by a contributor to or member of the organization as governing the action he contributes". Tetapi power need not be legitimate Artinya seseorang walaupun dibatasi kewenangannya dalam organisasi, ia bisa lebih berkuasa melebihi kewenangannya. Dari berbagai konsep kekuasaan tersebut di atas maka, kekuasaan dapat ditinjau dari berbagai perspektif, yaitu (1) Personal; (2) Politik; (3) Interpersonal; dan (4) Organisasi.

\section{c. Sumber kekuasaan}

Proses mempengaruhi meliputi tiga unsur yaitu: (1) orang yang mempengaruhi, (2) metode yang mempengaruhi, dan (3) orang yang dipengaruhi. ${ }^{14}$ Kekuasaan perlu dipertimbangkan tidak hanya dalam kaitannya dengan hubungan interpersonal, karena sub unit-sub unit dalam organisasi juga memiliki sejumlah kekuasaan yang beraneka ragam. Hasil yang ditimbulkan oleh kekuasaan dapat bermacam-macam, antara lain yang sangat kontradiktif, yaitu kepatuhan dan konflik.

Kekuasaan merupakan kapasitas untuk mempengaruhi secara unilateral sikap dan perilaku orang ke arah yang diinginkan ${ }^{15}$ Jenis Sumber kekuasaan : Position Power dibagi menjadi tiga yaitu:Legitimate Power,Coersive Power, Reward Power dan Rational Legal Authority. Personal power dibagi menjadi 6 yaitu: Expert Power, Referent Power,Information Power.,Connection Power dan Persuasive Power. Kekuasaan yang timbul karena ada kekuatan politik. political power dibagi menjadi 2, yaitu:Decision Making dan Coalisation.

\section{d. Taktik Kekuasaan}

Taktik kekuasaan merupakan strategi atau cara yang digunakan individu atau kelompok untuk menjabarkan landasan atau sumber kekuasaan ke dalam tindakan-tindakan tertentu untuk mempengaruhi pihak lain. ${ }^{16}$ Ada pun taktik kekuasaan yang bisa digunakan adalah sebagai berikut:Legitimasi, Persuasi rasional, Seruan inspirasional, Konsultasi,Tukar pendapat .Seruan pribadi,Menyenangkan orang lain, Tekanan dan Koalisi.

Dominica menjelaskan beberapa taktik dalam memperoleh kekuasaan sebagai berikut: Perubahan sosial, Aliansi, Identifikasi dengan otoritas tinggi,Pelayanan

\footnotetext{
${ }^{14}$ William G. Scott \& Terence R. Mitchell,Organization theory: a structural and behavioral analysis (Richard D. Irwin \& The Dorsey Press Publication,1972), hal.72

${ }^{15}$ Gary Yukl, Leadership in Organization. New Jersey: Pearson,1996),hal.183

${ }^{16}$ Robbins, S. P. Essential of Organizational Behavior $5^{\text {th }}$. Edisi Terjemahan Halida dan Sartika. (Jakarta: Erlangga,2005),hal.139

118| Falasifa, Vol. 11 Nomor 2 September 2020
} 
selektif,Kekuasaan dan simbol status dan Permainan kekuasaan serta Jaringan kerja. ${ }^{17}$ Gary Yukl mengemukakan pendapat lain mengenai taktik memperoleh kekuasaan, sebagai berikut.Perubahan, Tekanan, Persuasi rasional, Seruan inspirasional, Seruan personal, Konsultasi, Taktik legitimasi dan Taktik koalisi. ${ }^{18}$

\section{Strategi Kekuasaan Coercive Robert G. Owens}

Pendekatan power-koersif untuk mengubah keadaan organisasi berbeda secara signifikan dari yang empiris-rasional dalam penggunaanya (atau ancaman untuk menggunakan) sanksi dalam mendapatkan kepatuhan dari bawahanya. Sanksi biasanya bersifat politis, finansial, atau moral. Dalam sudut pandang power-koersif, rasionalitas, alasan, dan hubungan kemanusiaan semuanya adalah kemampuan sekunder untuk melakukan perubahan secara langsung melalui penggunaan kekuasaan. ${ }^{19}$

\section{Iklim Organisasi Inklusif}

Menurut Robert Stringer bahwa asset measurable properties of the work enviroment, based on the collective perception of the people who live and work in the enviroment and demonstrated to unfluencew there behafior. ${ }^{20}$ Artinya iklim organisasi sekolah merupakan seperangkat persepsi orang-orang hidup dan bekerja dalam suatu lingungan dan mempengaruhi perilaku mereka. Luthan mengatakan bahwa iklim organisasi adalah keseluruhan "perasaan" yang meliputi hal-hal fisik, bagaimana para anggota berinteraksi dan bagaimana para anggota organisasi mengendalikan diri dalam berhubungan dengan pelanggan atau fihak luar organisasi. ${ }^{21}$

Menurut Suharsaputra, mendefinisikan bahwa iklim organisasi merupakan hal yang amat penting bagi keberhasilan suatu organisasi dan iklim suatu organisasi akan sangat berbeda dengan iklim organisasi lainnya, karena hal tersebut berkaitan dengan kondisi lingkungan kerja masing- masing organisasi. Iklim organisasi juga merupakan konsep deskriptif yang berdasarkan pada persepsi lingkungan sosial anggota organisasi. ${ }^{22}$

\footnotetext{
${ }^{17}$ Dominica R. Lorbes. Influence, Power \& Politics in the Organisation. Organizational Behavior \& Development, 1 st Semester SY 2007-2008, hal. 3.

${ }^{18}$ Gary Yukl. Leadership in Organization (4th edition) Upper Saddle River, New York: Prentice Hall, 1998, hal, 208.

${ }^{19}$ Robert G. Owens. Organizatoinal Behavior in Education. (Allyn and Bacon. Boston,1995), hal.218

${ }^{20}$ Litwin \& Stringer. "Definisi Iklim Organisasi”, (http://jurnalsdm.blogspot.com), diakses 28 Juli 2015.

${ }^{21}$ Sopiah, Prilaku Organisasi, CV. Andi Offset, (Yogyakarta, 2008), hal. 130

${ }^{22}$ Suharsaputra, Udar, Administrasi Pendidikan. (PT. Rafika Aditama, Bandung, 2013), hal. 82.
} 


\section{Moh.Dasuki}

Sejalan dengan pendapat tersebut Marzuki menjelaskan bahwa iklim kerja di sekolah/madrasah adalah: keadaan sekitar sekolah/madrasah dan suasana yang 'sunyi dan nyaman' yang sesuai dan kondusif untuk pembelajaran yang dapat meningkatkan prestasi akademik". ${ }^{23}$ Dari beberapa pendapat para ahli diatas maka dapat didefinisikan bahwa iklim organisasi merupakan kondisi lingkungan kerja yang dirasakan oleh personal sekolah terhadap lingkungan sekolah, baik yang bersifat sosial, maupun akademik yang kondisi ini dirasakan secara individual.

\section{HASIL DAN PEMBAHASAN Strategi Power Edukatif Kiai Pada Pengembangkan Iklim Organisasi Inklusif}

Strategi Power kiai dalam pengembangkan Iklim Organisasi Inklusif di Pesantren tidak bisa dipisahkan dalam tradisi kepemimpinan Kiai. Aktivitas kepemimpinan sebagaimana yang dijelaskan Gibson bahwa kepemimpinan adalah ikhtiar dengan menggunakan suatu pola untuk mempengaruhi tampa paksaan serta adanya motivasi untuk mencapai tujuan. Disini jelas dapat digaris bawahi bahwa aktivitas kepemimpinan tidak lain adalah proses pengaruh-mempengaruhi untuk mencapai tujuan dalam hal ini tujuan asasi didirikannya pesantren adalah tafaqohu fiddin.

Kata kunci untuk membuka wawasan kepemimpinan pesantren adalah tafaqohu fiddin meskipun organisasi yang ada dibawah naungan pesantren tidak semuanya berorintasi secara langsung pada kehidupan beragama, namun organisasi atau lembaga-lembaga itu menjadi jalan untuk kepentingan agama, oleh karena itu dalam kepemimpinan kiai, simpul-simpul agama dan simbol religiusitas menjadi daya gerak dalam kepemimpinan kiai, sehingga organisasi yang digelutinya dengan mudah ia kendalikan dengan baik, karena kecerdasan spritualitasnya yang telah mendorong pemimpin untuk membuat nyaman para bawahannya.

Kiai dalam proses kepemimpinan adalah seseorang yang memang dilahirkan dan dibentuk untuk meneruskan estafet kepemimpinan, oleh sebab itu para orang tua mereka mengirim putra mahkotanya untuk mendalami ilmu agama dan ilmu-ilmu penopang lainnnya. Dalam banyak hal biasanya putra mahkota ini dikirim kepondok-pondok terkenal dan besar yang memiliki budaya akademik pesantren yang kuat dan pendirinya adalah kiai-kiai yang memiliki spesialisasi keilmuan tertentu tentunya masih dalam kultul ilmiah yang bermazhab alhlussunah waljama'ah.

Kiai Sebagai seorang pemimpin biasanya banyak dibesarkan dilingkungan yang berkultur alhlussunah waljama'ah sebagaimana dikatakan oleh Azyumardi Azra bahwa pesantren sebagai 


\section{Strategi Power Edukatif Kiai Pada Pengembangkan Iklim Organisasi}

lembaga yang indigenous, yang muncul dan berkembang dari pengalaman sosiologis dan memiliki keterikatan yang tidak bisa dipisahkan dengan masyarakat lingkungannya sedangkan M. Nuhrison Nuh dalam Peranan Pesantren dalam Mengembangkan Budaya Damai mengatakan bahwa Komunitas pesantren tidak diragukan lagi adalah bagian dari masyarakat Ahl As-Sunnah wa-l-Jamaah (Aswaja) yang merupakan mayoritas muslim yang menerima otoritas Sunnah Rasul dan seluruh generasi pertama (sahabat) serta keabsahan sejarah komunitas Muslim. ${ }^{24}$

Begitu pula dengan keberadaan KH.Achmad Muzakki Syah dan KH.Muhyidin Abdusshomad lahir dari keluarga taat beragama yang berhaluan Ahlussunnah waljama'ah. Sebagai kiai yang besar dilingkungan tradisi ahlussunah waljama'ah jelas beliau mewarisi cara berfikir dan amaliyah ahlussunah waljama'ah yang kelah mengantarkan mereka berdua sebagai kiai yang memiliki pandangan-pandangan moderat dalam mengendalikan pesantrennya.

Kepemimpinan Kiai yang demokratis dibentuk oleh iklim keluarga, pendidikan dan cara pandang keagamaan yang cukup moderat sehingga keduanya menjadi sosok yang cukup disegani baik ditingkat lokal, nasional dan bahkan ditingkat regional. Telah banyak kontribusi keduanya baik bagi pesantren dan masyarakat.kedua kiai memiliki pesona kepemimpinan yang berbeda dalam prakteknya, KH.Achmad Muzakki Syah terkenal Imam Besar Manaqib yang memiliki ribuan santri dan Jama'ah.

Praktek kepemimpinan dan kontribusinya banyak bergerak dibidang kultural NU terutama pada aktivitas pengajian dan manaqib, sosokya pula memiliki sikap kepemimpinan yang selalu istiqomah ibadah, pendapat dan perjuangannya, Ahli Riyadhah, ahli tirakat dan sering berkhalwat serta terkenal sabar dan dermawan. Tidak berlebihan bila KH.Achmad Muzakki Syah adalah sosok pemimpin yang memiliki akar kultural dan spritual yang kuat.

Nilai-nilai pendidikan pesantren merupakan bentuk prilaku yang telah menjadi kebiasaan Kiai, sama halnya dengan kepribadian atau praktek ibadah yang dilakukan oleh KH.Achmad Muzakki Syah yang sudah menjadi sikap kepemimpinannya. Sikap religius Kiai menjadi model kepemimpinan yang dapat menjadi teladan bagai bawahannya.selain sebagai model dalam praktek kuasa politik kiai dalam pendidikan, sebenarnya sikap itu adalah nilai-nilai yang ditransmisikan oleh pemimpin kepada bawahannya. Dalam politik pendidikan yang dijalankan oleh kiai, lebih banyak kepada interakasi edukatif dari pada interaksi yang hanya bersifat politis.

\footnotetext{
${ }^{24}$ M. Nuhrison Nuh (Editor), Peranan Pesantren dalam Mengembangkan Budaya Damai (Jakarta: Balitbang Kemenag, 2010), hal.24 


\section{Moh.Dasuki}

Prinsip kepemimpinannya yang terkenal yaitu kemualian dengan usaha bukan karena nasab. Jiwa demokratis beliau terlihat pada prinsip kepemimpinannya. Jadi banyak hal yang ditemukan pada kepemimpinan Pesantren Al-Qodiri.

Begitu pula dengan sosok KH.Muhyidin Abdusshomad yang terkenal sosok yang aktif menulis karya intlektual keaswajaan serta memiliki Sikap kepemimpin yang sabar, low profile, tegas dan konsisten.selain kesibukannya sebagai pengasuh dipesantren, beliau pula sosok aktivis struktural NU, sehingga tidak berlebihan sosoknya menjadi pemimpin yang memiliki basis struktural dan intlektual yang kuat diakar rumput. Dan seni memimpin ini yang diadopsi kedalam pesantren atau seni kepemimpinan pesantren yang diadopsi kedalam stuktural NU.

Struktur dan kultur NU memberi andil besar bagi pola kepemimpinan yang dimilikinya, di NU KH.Muhyidin Abdusshomad menjadi sosok yang cukup disegani karena kepemimpinannya telah mewarnai kehidupan organisasi keagamaan inklusif dan moderat di Jember. Sosoknya selain sebagai seorang ulama'kharismatik beliau juga seorang organisatoris, bekal inilah yang menjadi social capital dirinya dalam membangun organisasi di NU dan Pesantren Nurul Islam.

Kekuatan kultural dan struktural ini yang banyak diincar oleh pesohor kekuasaan untuk mendulang suara-suara partai dan para calon baik dalam momentum pileg, pilpres dan pilkada. Namun hak politik ini kiai yang lebih paham. Power kultural dan struktural cukup strategis bila digunakan untuk mengembangkan lembaga pendidikan dimana modal ini sudah mencover relasi vertikal dan horizontal.

Sukamto mengatakan Kepribdian dasar dan sikap kepemimpinan dari kedua figur itu adalah kiai yang memiliki otoritas karismatik karena ketinggian ilmu agama, kesalehan dan juga

pesona kepemimpinan. ${ }^{25}$ Kondisi inilah yang menjadikan Kiai diposisikan oleh masyarakatnya sebagai uswatun hasanah (role model), atau contoh panutan yang baik di dalam lingkungan masyarakatnya.

Pola kepemimpinan, akar jaringan dan kekuatan kepemimpinan menjadi modal potensial dalam mempengaruhi orang lain. ${ }^{26}$ Jadi ada beberapa modal kepemimpinan demokratis dan kharismatik pesantren Al-Qodiri dan Pesantren Nurul Islam yaitu modal kultural- struktural dan kapabilitas intlektual serta spritual.

\footnotetext{
${ }^{25}$ Sukamto, Kepemimpinan Kiai dalam Pesantren, (Jakarta: LP3ES, 1999), hal.358

${ }^{26}$ Luthan, Fred, Organizational Behavior ...hal.433

122| Falasifa, Vol. 11 Nomor 2 September 2020
} 


\section{Strategi Power Edukatif Kiai Pada Pengembangkan Iklim Organisasi}

Ikatan emosional, intlektual bahkan spritual Kiai-santri akan terus berlanjut hingga membentuk pengaruh kiai ditingkat kultural yaitu pengaruh kiai dimasyarakat bawah karena kiai telah menancapkan pengaruh strukturalnya saat berada dipesantren melalui otoritas dan kebijakan-kebijakan yang berhubungan dengan seluruh aktivitas pendidikan dipesantren.

Jadi faktor lingkungan keluarga, pendidikan dan lingkungan sosial turut serta dalam membentuk power yang dimiliki oleh kiai.bangunan lingkungan ini sebagai modal penting dalam mengkonstruksi kognisi, emosi dan afeksi kiai dalam mempengaruhi bawahannya didalam organisasi.rekam jejak kepemimpinan kiai sebenarnya cukup mudah dilacak berdasarkan rekam geniologi keluarga dan keilmuannya.

Perlu dibedakan kekuasaan yang ada di lembaga-lembaga atau organisasi yang ada, sehingga nampak jelas pola power atau kekuasaan yang muncul baik sumber dan penggunaannya dilembaga-lembaga yang ada. Ada lembaga profit dan lembaga non profit atau lembaga jasa pendidikan. Menurut lord yang dikutip oleh Fremonth bahwa kekuasaan cendrung korup, ${ }^{27}$ pernyataan ini mungkin benar bila diorganisasi profit dan lembaga politik, sementara di pesantren justru sebaliknya, kekuasaan dimanfaatkan untuk taqorrub ilallah.

Belum ditemukan indikasi korupsi kekuasan yang dilakukan oleh kiai bahkan para kiai itu mendidikasikan diri dan hartanya untuk kepentingan berjuang dijalan Allah sebagaimana yang telah dilakukan oleh KH.Achmad Muzakki Syah dan KH.Muhyidin Abdusshomad. Mungkin potensi korup itu ada bagi lembaga-lembaga yang tidak diikat oleh ikatan religius yang kuat sehingga agama menjadi alat untuk mengontrol tanggungjawab yang dilakukan oleh pemimpin.berbeda dengan lembaga yang hanya kuat ikatan ideologis dan sosiologis potensi korupsi cukup terbuka karena masing-masing yang berada dizona aman kekuasaan biasanya matimatian akan menjaga status qou-nya.

Bicara power atau kekuasaan bisa dilihat dari berbagai persepektif diantaranya persepektif personal, politik, interpersonal dan organisasi. Pada persepektif personal dianggap bahwa seseorang membutuhkan kekuasaan, namun dipesantren para kiai itu sudah secara otomatis memiliki kekuasaan yang melakat pada dirinya karena berbagai modal kapital yang dimilikinya baik dia sebagai orang yang dibesarkan dari keluarga yang berpengaruh, karena faktor pendidikan dan lingkungan, ideologi kegamaan dan aktivitas organisasi, bahkan karena kepribadiannya.ini

\footnotetext{
${ }^{27}$ Fremonth E. Kast and Rosenzweig, Organisasi dan Manajemen: Alih Bahasa. Jakarta: Bumi Aksara,2002),hal.517
} 


\section{Moh.Dasuki}

tentu tidak cocok bila direlevansikan dengan kondisi dipesantren. Organisasi pesantren bukan ajang perebutan kekuasaan, meskipun pratek kekuasaan terjadi. Proses pencarian kakuasaan tidak ada karena otoritas tertinggi ditangan kiai yang memiliki kharisma tinggi.

Begipula bila kekuasaan pesantren dilihat dari persepektif politik maka sangat tidak cocok meskipun aktivitas pengaruh-mempengaruhi ada dipesantren.politik yang diterapkan dipesantren tidak lain adalah untuk mengatur pesantren. Karena itu dalam memimpin pesantren dengan jiwa yang demokratis dan kharismatik maka KH.Achmad Muzakki Syah dan KH.Muhyidin Abdusshomad memiliki prinsip, kemuliaan itu bukan didapat dengan nasab keturunan, tapi dengan upaya.hal ini lebih pada optimalisasi ikhtiar dari pada faktor keturunan selain itu ada prinsip kepemimpinan 6 S (Sopan, Santun, Salam, Sapa, Senyum dan Sanjung) yang dijalankan dalam mengendalikan organisasi.

Prinsip kepemimpinan ini dapat menjadi sumber kekuatan pemimpin dalam mengendalikan bawahannya. Para bawahan merasa senang dengan pemimpin yang berprinsip, lebi-lebih prinsipnya mengutamakan prinsip kerja keras dari pada mengandalkan keturunan.Kerja keras itu kemudian didukung oleh sikap yang Santun, Salam, Sapa, Senyum dan Sanjung kepada bawahannya.

Enam (S) mengandaikan kekuatan profetik pada diri pemimpin, bahwa memang seperti itu layaknya seorang pemimpin yang dihargai oleh bawahannya.Organisasi inklusif yang menjadi tujuan tersebut akan cepat dirasakan oleh para bawahannya karena pemimpin sendiri telah mencoh nabi dalam memimpin ummatnya meskipun tidak seratus persen sama.

Model leadership profetik kiranya beririsan dengan Penelitian Nirmalawati yang berjudul Hubungan antara Kapabilitas Kepemimpinan, Kompetensi Dosen, Komitmen Dosen, dan Akuntabilitas Lembaga dengan Kinerja Lembaga dalam Pelaksanaan Penjaminan Mutu pada Universitas Negeri di Jawa Timur yang berkesimpulan bahwa makin tinggi kapabilitas kepemimpinan diikuti makin tingginya kinerja lembaga dalam pelaksanaan penjaminan mutu, asalkan disertai akuntabilitas lembaga yang tinggi, makin tinggi kapabilitas kepemimpinan diikuti makin tingginya kinerja lembaga dalam pelaksanaan penjaminan mutu, asalkan disertai komitmen dosen dan akuntabilitas lembaga yang tinggi.

Jadi kapabilitas seorang pemimpin menjadi daya yang cukup besar untuk memompa mutu dan akuntabilitas organisasinya.begitupula dengan prinsip-prinsip kepemimpinan KH.Achmad Muzakki Syah dan KH.Muhyidin Abdusshomad yang dapat membentuk tatanan organisasi yang 
loyal dari bawahannya. Kapabiltas dan akuntabilitasnya beliau tunjukkan malalui prinsip-prinsip yang ia bangun sendiri baik kerja kerasnya, Santun, Salam, Sapa, Senyum dan Sanjung kepada bawahannya yang membuat kiai tersebut berpengaruh sebagai pemimpin baik bagi orang-orang internal organisasi maupun orang esternal organisasi.

Oleh sebab itu kekuasaan merupakan kapasitas untuk mempengaruhi secara unilateral sikap dan prilaku orang kearah yang diinginkan. Gery Yukl (1996) mengatakan bahwa ada beberapa sumber kekuasaan. Pertama, position power yang terbagi menjadi legitimate power, coersive power, reward power dan rational legal authorithy. ${ }^{28}$

Pada posisi legitimate power dua pesantren ini tidak bersumber pada itu sebab legitimate power tidak diberikan oleh suatu organisasi, namun diberikan oleh masyarakat secara umum, sehingga kekuasaan itu dibeikan oleh masyarakat umum dengan demikian maka kakuasaan kiai adalah pengakuai masyarakat luas jadi kakuakasannya bisa menjadi public power karena keberadaan kekuasaan ini diberikan oleh masyarakat sebagaimana Martin Van Bruinessen yang mengatakan Gelar Kiai tidak diusahakan melalui jalur-jalur formal sebagai sarjana misalnya, melainkan datang dari masyarakat yang secara tulus memberikannya tanpa intervensi pengaruhpengaruh pihak luar. ${ }^{29}$

Pengakuan secara tulus dari masyarakat itu pada akhirnya kiai diberi hak preogratif dalam masyarakat untuk mempengaruhi seluruh aktivitas kehidupan masyarakatnya. Pengaruh ini datang karena sebuah kharisma yang dimiliki oleh kiai yang mampu mempengaruhi baik fisiologis, psikis bahkan pengaruh teologis bawahannya.

Kekuasaan KH.Achmad Muzakki Syah diberikan oleh masyarakat karena beliau dipandang sosok yang punya kharisma dengan kekuatan spritual yang memiliki akar kultural yang kuat sementara KH.Muhyidin Abdusshomad memiliki pesona kharisma dengan kekuatan intlektual yang mempuni, memiliki akar struktural yang kuat ditubuh NU.

Coersive power tidak ditemukan dipesantren meskipun pemimpin yang kharismatik juga menggunakan cara-cara otoriter pada bawahanya,justru beliau sering memberikan nasehatnasehatnya pada bawahannya dengan nasehat agar bawahannya selalu istoqomah, jujur, selalu

\footnotetext{
${ }^{28}$ Gary Yukl, Leadership in Organization. hal.183

${ }^{29}$ Martin van Bruinessen. Pesantren and Kitab Kuning: Continuity and Change in a Tradition of Religious Learning. Dalam Wolfgang Marschall (ed). Texts from the Islands: Oral and Written Traditions of Indonesia and the Malay World (Etnhnologica Bernensia). Berne: The University of Berne Institute Ethnology, 1994
} 


\section{Moh.Dasuki}

bermanfaat, jangan membesar-besarkan diri serta tawadhu, jangan mengecewakan (costumer), Menghargai orang lain, merebut hati orang dan bagaimana cara menghadapi orang, tidak arogan, mau mendengar dan bermusyawarah, jangn mencaci dan jangan meremehkan.

Kenyataan di Pesantren Al-Qodiri dan Pesantren Nurul Islam berbalik arah dengan Strategi Kekuasaan Coercive Robert G. Owens yang mengatakan bahwa Pendekatan powerkoersif untuk mengubah keadaan organisasi berbeda secara signifikan dari yang empiris-rasional dalam penggunaanya (atau ancaman untuk menggunakan) sanksi dalam mendapatkan kepatuhan dari bawahanya. Sanksi biasanya bersifat politis, finansial, atau moral. Dalam sudut pandang power-koersif, rasionalitas, alasan, dan hubungan kemanusiaan semuanya adalah kemampuan sekunder untuk melakukan perubahan secara langsung melalui penggunaan kekuasaan. ${ }^{30}$

Strategi Kekuasaan Coercive Robert G. Owens cocok bila digunakan pada organisasi profit dan politik dimana para anggota organisasi diikat oleh ikatan materil sehingga potensi membuat ketergantungan pada bawahannya cukup timggi.Pesantren tidak menggunakan ikatan materil yang mengikat mereka, namun ikatan yang dibentuk dalam organisasi pesantren lebih banyak pada ikatan emosional, sebab mereka yang berada dalam organisasi tidak hanya mengikat tanggungjawabnya pada kiai namun pada tali agama.

Dari gambaran itu maka sumber kekuasaan kiai tersebut adalah karena beliau berdua sering memberikan nasehat-nasehat kepemimpinan yang baik sehingga nasehat (advice)-nya menjadi pengaruh besar bagi bawahannya. Parektek nasehat-nasehat ini mendorong lembaga menjadi cukup inklusif, karena posisi memimpin dimata bawahannya bukan orang yang ditakuti tapi disegani, inilah bedanya coersive power dengan advice power antara kekuasaan memaksa dan kekuasaan menasehati. Kekuasaan yang seharus dapat memaksa ditangan kiai justru nasehatnasehat dirinya yang dapat memaksa jiwa bawahannya untuk tunduk terhadap kebaikan-kebaikan yang ditanaman oleh kiai.

Nasehat-nasehat itu tidak hanya hiasan kata, tetapi ada warisan nilai-nilai pemimpin yang diberikan pada para personalia, agar senantiasa menjungjung tinggi nilai-nilai kemanusian dan ketuhanan. Pembelajaran nilai-nilai ini menjadi indikasi bahwa sosok kiai tidak hanya sebagai pemimpin dan manajer tetapi juga menjadi sosok edukator yang memberi cerminan nilai dan pengetahuan.

\footnotetext{
${ }^{30}$ Robert G. Owens. Organizatoinal Behavior in Education..hal.218 126| Falasifa, Vol. 11 Nomor 2 September 2020
} 


\section{Strategi Power Edukatif Kiai Pada Pengembangkan Iklim Organisasi}

Power kiai juga bersumber dari reward power, KH.Achmad Muzakki Syah dan KH.Muhyidin Abdusshomad selalu memberikan Apresiasi berupa ucapan, fasilitasi dan penghargaan materi serta perhatian langsung secara dhohiriyah sehingga bawahnnya sungkan pada kiai. Meski kiai tidak butuh kekuasaan namun karena watak kepemimpinan itulah kiai disegani oleh bawahannya.

Apresiasi berupa ucapan, mungkin tidak seberapa bagi para personalia didalam organisasi, namun apresiasi verbal itu mampu mendorong semangat bawahannya, bayangkan bila yang muncul adalah kata-kata yang tidak baik atau komunikasi yang tidak membangun jelas akan memicu munculnya konflik antara atasan dan bawahan.pemberian ucapan yang baik sebaliknya dapat menjaga keutuhan rumah tangga organisasi.memang konflik juga penting dalam organisasi, jauh lebih penting dari pada itu hubungan harmonis dan kondusif harus diciptakan oleh pemimpin dan bawahannya salah satunya dengan penghargaan melalui ucapan-ucapan yang positif.

Fasilitasi dan penghargaan materi juga ikut mendorong bawahan bekerja dengan baik. Pemimpin yang hebat tentu tahu betul bagaimana kebutuhan bawahannya baik menggunakan cara fasilitasi terhadap kebutuhannya maupun penghargaan materi.penghargaan ini hal yang wajar yang tentu diterima dengan senang hati oleh para bawahannya, semakin tinggi kompensasi atau hadiah-hadiah yang diberikan pada bawahnnya maka biasanya berbalik besar juga daya yang dihasilkannya, bagaimanapun manusia memiliki tingkat sensitifitas yang tinggi bilamana diperhatikan oleh atasan-atasannya atau oleh orang lain yang dianggap memiliki banyak kelebihan-kelebihannya, apalagi sekelas KH.Achmad Muzakki Syah dan KH.Muhyidin Abdusshomad yang memperhatikan bawahannya.

Sumber reward ini bukan hal yang disengaja dilakukan oleh kiai untuk mendulang kepentinganya, karena kiai tidak dalam rangka memburu kekuasaan, namun keduanya sedang dalam menjaga eksistensi pesantren.Reward power tersebut hal yang biasa dilakukan oleh kiai karena kiai sudah terbiasa, dan kiai serta keluarganya adalah orang-orang dermawan.jadi kedermawanan itu yang membuat dirinya selalu hadir, memfasilitasi dan mengayomi para bawahannya.

Dalam persepektif teori kuasa organisasi maka yang dilakukan oleh dua sosok kiai tersebut adalah sebagai sumber dalam menghasilkan pengaruh yang besar, diakui atupun tidak. Reward power memberi ruang terhadap kuasa pemimpin terhadap bawahannya, meskipun tidak dalam rangkan menciptakan ketergantungan antara atasan dan bawahan. Reward power model 


\section{Moh.Dasuki}

kiai ini tidak lain adalah sebagai upaya menjaga eksistensi pesantren dan wujud perjuangan beliau untuk menegakkan agama Allah. Reward power dalam konteks organisasi adalah salah satu instrumen penting bagi seorang pemimpin sebagai sumber pengaruh untuk mengendalikan bawahan-bawahannya. Reward power terbatas pada pemberian materi dan pemberian jabatan tertentu, rasanya dipesantren materi juga diberikan namun jabatan bukanlah satu-satunya tetapi tanggungjawab yang diberikan kiai pada bawahannya.

Pada konteks pesantren yang cocok sebenarnya bukan Reward power namun istilah yang cocok adalah apresiatif power yaitu bentuk perhatian baik dhohir dan batin yang dilakukan oleh kiai untuk menghargai prestasi dan kinerja bawahannya. Kiai tidak hanya mengayomi kebutuhan fisik para anggotanya tetapi juga kebutuhan psikis para anggotanya sehingga Reward power kurang representatif untuk menggambarkan sumber-sumber pengaruh yang dimiliki oleh Kiai hingga menghujang kearus bawah. Begitupula dengan Position Power di pesantren, kiai memiliki kewibaan formal yang tidak dapat dari organisasi forlmanya namun diberikan oleh masyarakat luas karena sumber pengaruhya dari berbagai farktor, jadi Position Power itu bersumber dari kekuatan informal yaitu pengakuan masyarakat sehingga posisi itu bisa menjadi Public power atau pengaruh informal.

Jenis sumber kekuasaan lainnya adalah personal power dalam hal ini KH.Achmad Muzakki Syah dan KH.Muhyidin Abdusshomad memiliki keperibadian yang dapat mempengaruhi diantaranya. Expert power kepemimpinan KH.Achmad Muzakki Syah dan KH.Muhyidin Abdusshomad karena beliau dibesarkan dari lingkungan pendidikan pesantren yang mengetahui betul bagaimana kiai memimpin, dari gaya masing-masing kiai yang memimpin tersebut maka kiai terpengaruh oleh gaya kepemimpinan para kiainya, disamping itu gaya kiai memimpin juga dipngaruhi oleh aktivitas kiai baik distruktur dan kultur organisasi keagamaan jadi pengalaman itu yang membuat kiai KH.Achmad Muzakki Syah dan KH.Muhyidin Abdusshomad cukup ahli dalam memimpin pesantren.

Keahlian memimpin organisasi karena kiai banyak bersinggungan dengan banyak orang, banyak watak dan banyak kepentingan sehingga beliau dengan kehlian yang luar biasa itu dapat menjalankan roda organisasi dengan baik.selain kekuasaan ahli, KH.Achmad Muzakki Syah dan KH.Muhyidin Abdusshomad memiliki referens power yang bersumber dari Sikap kepemimpinannya yang tegas, sabar dan Istoqomah, low profile, Ahli Riyadhah, ahli tirakat dan sering berkhalwat serta dermawan. 
Teladan beliau tidak hanya teladan yang berhubungan dengan relasi kemanusian saja namun lebih dari sekedar itu memiliki relasi ketuhanan. Pemimpin yang semacam ini tidak hanya bertujuan untuk memberi tempat pada sisi kemanusiannya, namu juga pada sisi ketuhanan. Dengan pendekatan dua demensi itu maka referens power berdemensi integratif yaitu demensi teologis dan demensi sosiologis.

Kekuasaan semacam itu menjadikan bawahan mendapat suasana yang cukup posistif dimana setiap kinerejanya akan dihargai dengan baik, buktinya para kiai itu begitu tinggi penghargannya pada bawahannya, baik secara ferbal, fasilitiasi dan pengayoman.biasanya dalam organisasi hanya orang-orang yang berprestasi dan berkinerja tinggi yang diberikan apresiasi oleh para pemimpinnya untuk memacu kinerja yang lebih baik lagi.namun sebaliknya kiai memberikan imbalan dan apresiasi yang layak berdasarkan prestasi pada semua bawahannnya, sehingga antara yang punya dan tidak memiliki prestasi merasa nyaman dengan kiai.

Information power dan conection power juga didapat oleh KH.Achmad Muzakki Syah dan KH.Muhyidin Abdusshomad karena beliau berdua memiliki banyak koneksi akar kultural dan struktural,hal itu telah membuat beliau memiliki pengaruh yang luar biasa baik lokal, nasional dan regional. Pengaruhnya yang luas itu menjadikan beliau memiliki banyak pengatahuan dan informasi karena bersinggungan dengan banyak orang. Interaksi inilah yang membuat para pemimpin tersebut semakin matang karena dealektika yang dilakukannya.

Pada pengaruh struktural, biasanya hubungan ini cukup bererokratif karena melibatkan unsur-unsur formal dalam organisasi. Hubungan struktural lebih pada hal-hal yang bersifat politis karena melibatkan berbagai kepentingan organisasi sehingga relasi ini sulit untuk bisa didentifikasi sebab masing-masing eleman memilik motif tersendiri.begitu pula masing-masing personal memposisikan diri status yang dimilikinya sehingga kaduanya sama-sama diikit oleh hubungan yang bersifat fungsional.

Sedikit berberbeda dengan koneksi kultural yang memiliki relasi berbeda dengan kepentingan saling menguntungkan secara politis, akar kultural menjadi penghubung antara massa dengan pemimpinnnya.ikatan hubungan ini biasanya memposisikan pemimpin sebagai orang yang mampu membimbing sedala demensi bawahannya baik demensi material lebih-lebih demensi spritual, tidak berlebihan bilan kiai memiliki Doble conection power yaitu koneksi kultural dan koneksi struktural. 


\section{Moh.Dasuki}

Persuasive power, jenis pengaruh ini memberi kekuatan pada kiai karena kiai selalu memberi persuasi terhadap penguatan kepribadian baik bagaiman cara menghargai diri sendiri dan menghargai orang lain. Dengan mendorong bawahannya seperti itu maka bawahan akan mendedikasikan dirinya secara sukarela. Power Kiai tidak berhenti pada bagaimana kiai melakukan tindakan persuasif untuk mendorong bawahannya melakukan kegiatan-kegiatan yang produktif.otoritas lain yang dimiliki oleh kiai dalah tradisional power jelas sebagai orang yang memiliki kedalaman ilmu kiai banyak didik oleh keluarganya sendiri sehingga sanad dan tindakan keilmuan bahkan karakter kiai terbentuk didalam keluarga sebelum mereka tumbuh besar dan dikirim kepesantren-pesantren lain untuk memantabkan keilmuannya.

KH.Achmad Muzakki Syah dan KH.Muhyidin Abdusshomad besar dilingkungan itu sehingga transformasi nilai-nilai tradadisional mengalir deras dalam benaknya yang kemudan hari karakter dan warisan nilai-nilai ini yang menjadi kekuatan untuk memimpin banyak orang.latar belakang keluarga dan kultur tradisional memberi andil besar bagaimana pengaruh dua tokoh tersebut dalam kehidupan masyarakat.

Tradisional power beririsan dengan kultur kegamaan yang menjiwai dua tokoh tesebut.tidak heran bila dua pesantren yang menjadi asuhannya menjadi pesantren yang inklusif dan memiliki berbagai keunggulan-keunggulan didalamya. Tradisi salaf tetap terpelihara sampai saat ini, karena sejak awal pesantren di Nusantara untuk melestarikan tradisi salaf dan kultur aswaja.maka tidak heran pesantren-pesantren dengan pola ini menjadi pesantren yang aktif menyuarakan perdamian, kebangsaan dalam bingkai Islam rahmatal lil alamin, beda dengan pesantren yang baru saja muncul dan para pemimpinnnya berafiliasi dengan kelompok-kelompok radikal ditimur tengah, kecendrungan pesantren ini eksklusif dengan masyarakat umum.

Dari gambaran tersebut maka sumber-sumber kekuasaan ini kemudian dijalankan oleh kiai dengan beberapa taktik kekuasaan sebagaimana yang diidentifikasi oleh Robbins ${ }^{31}$ namun taktik yang dilakukan sebagaimana identifikasi tersebut seruan inspirasional, tukar pendapat, seruan pribadi dan menyenangkan orang lain dalam hal ini taktik banyak dilakukan melalui apresiasi, sharing, fasilitasi dan motivasi. Maka taktik kakuasaan meskipun tampa disadari oleh KH.Achmad Muzakki Syah dan KH.Muhyidin Abdusshomad dalam membangun organisasi inklusif di pesantren, karena mereka berdua adalah sosok yang tegas, sabar dan Istoqomah, low

${ }^{31}$ Robbins, S. P. Essential of Organizational Behavior $5^{\text {th }}$. hal.139 
profile, Ahli Riyadhah, ahli tirakat dan sering berkhalwat serta dermawan.hal ini tentu yang membuat orang lain terpengaruh atau kiai mampu mempengaruhi hidup khalayak lebih-lebih para pembantunya di organisasi pesantren dan lembaga pendidikan.

Taktik apresiasi sering dilakukan kiai melalui pemberian ucapan-ucapan verbal pada bawahannya yang memiliki prestasi dan kinerja baik. Begitupula halnya dengan fasilitasi terhadap kebutuhan baik pangan, sandang dan papan para bawahannya kiai memperhatikan itu semua baik melalui insentif dan penyedian kebutuhan secara langsung.tidak terkecuali itu Sharing juga sering dilakukan karena kiai menempatkan para bawahannya sebagai orang-orang yang memiliki inisitiatif perubahan, makanya ruang curah gagasan itu banyak lahir dari ide-ide bawahannya. Taktik kekuasaan lebih banyak karena faktor personalia kiai yang menjadi magnet bagi banyak orang. Kekuatan intlektual, emosional ditambah dengan kekuatan spritual itu mungkin bagi banyak santri, pengurus dewan guru, alumni, simpatisan, wali santri dan seluruh lapisan masyarakat merasa nyaman dengan beliau berdua. Karena itu modal tiga serangkai ini yang menjadi power politik pendidikan kiai dalam mengembangakan organisasi inklusif pesantren.

Dominica mengatakan bahwa taktik memperoleh kakuasaan itu karena beberapa hal diantaranya karena simbol status dan jaringan kerja.sekali lagi kekuasaan KH.Achmad Muzakki Syah dan KH.Muhyidin Abdusshomad tidak diperoleh melalui pencarian namun karena faktor pemberian publik jadi publik memberikan kekuasaan ini karena kiai memiliki kepampuan dalam bidang agama dan mempu membing ruhaniyah banyak orang sehingg wajar bila seseorang yang memiliki kompetensi semacam ini terutama di Jawa disebut Kiai. Dengan diberikan gelar kiai itu maka secara otomatis melekat dalam dirinya pemimpin keagamaan yang memiliki otoritas dalam memberikan bimbingan dan pencerahan agama. ${ }^{32}$

Status itulah yang mejadi instrumen dalam mempengaruhi orang lain dan bawahannya agar sesuai dengan yang digariskan agama. Ini sedikit berbeda dengan para pemmpin lainnnya, karena banyak pemimpin organisasi hanya ditakuti tetapi tidak disegani, kiranya KH.Achmad Muzakki Syah dan KH.Muhyidin Abdusshomad adalah sosok yang disegani karena kepribadian beliau dan kemampuan beliau baik dibidang intlektual dan spritual.

${ }^{32}$ Dominica R. Lorbes. Influence, Power \& Politics in the Organisation. hal. 3. 


\section{Moh.Dasuki}

Terbentuknya cara pandang dan sikap bawahannya itu karena kiai selaku sosok Edukator. KH.Achmad Muzakki Syah dan KH.Muhyidin Abdusshomad telah mengajarakan pada bawahnnya agar senantiasa tegas sabar dan Istoqomah, low profile, dermawan serta banyak mendekatkan diri pada dzat transendental yang bertujuan agar memperoleh inspirasi-inspirasi kebaikan.

Selanjutnya faktor terbentuknya iklim organisasi yang lain yaitu Tingkah laku kelompok . Terdapat kebutuhan tertentu pada kebanyakan orang dalam hal hubungan persahabatan, suatu kebutuhan yang seringkali dipuaskan oleh kelompok dalam organisasi. Pada level ini keakraban yang dibangun oleh kiai melalui berbagai momentum penting misalnya yang dilakukan oleh KH.Achmad Muzakki Syah dan KH.Muhyidin Abdusshomad memiliki forum silaturrahim bulanan, dan Forum konsolidasi mingguan untuk menjlis pengasuh. Artinya keakraban itu telah dipupuk secara sempurna oleh kiai, wadah ini menjadi wadah dalam membangun keakraban antar anggota organisasi, dimana forum silaturrahim ini sebagai ruang untuk melakukan berbagai hal untuk kepentingan pesantren.

Forum silaturrahim bulanan, dan Forum konsolidasi mingguan untuk menjlis pengasuh sekaligus mejadi media kontrol kekuasaan kiai terhadap bawahannya.diakuia atau tidak kontrol kekuasaan melalui jalinan silaturrahim ini memiliki peran penting dalam mengontrol kekuasaan kiai dalam membangun organisasi inklusif. Kiai mampu menghangatkan suasana,mendekatkan yang jauh, menyelesaikan yang tidak selesai dan dapat mengetahui seluruh aktivitas organisasi baik perkembangan dan kendalanya.

Penghargaan setingginya terhadap inesiatif ini menjadikan iklim organisasi menjadi iklim yang kondusif. Meski pesantren terkenal seperti kerajaan, namun pola kepemimpinannya tidak seperti monarkhi sebagaimana kerajaan pada umumnya dimana raja dianggap orang yang memiliki keputusan absolut.Dinamika kepemimpinan organisasi sudah mulai bergeser dari otoriter ke demokratis, hal itu sejalan dengan kebutuhan jaman dan dinamika masyarakat didalamnya, apalagi para pemimpinnya yang sudah memiliki pandangan yang luas karena faktor pendidikan dan lingkungan yang cukup terbuka dengan sebuah perbedaan.

Penghragaan KH.Achmad Muzakki Syah dan KH.Muhyidin Abdusshomad pada bawahannya cukup tinggi mulai dari fasilitasi kebutuhan papan dan sandangnya, juga penghargaan pada kebutuhan pangannya.Tidak hanya berhenti disana,kiai juga memperhatikan secara dhohir terhadap aktivitas yang dilakukan oleh bawahannya.oleh karenanya penghargaan 132| Falasifa, Vol. 11 Nomor 2 September 2020 
yang tinggi ini kemudian yang menjadikan kiai mendapatkan pengaruhnya yang cukup besar dalam mengendalikan pesantren.

\section{KESIMPULAN}

Kekuasaaan kiai merupakan jati diri kepemimpinannya yaitu kepemimpinan demokratis dan kharismatik. Sumber kekuasaan kiai didapat dari sikap dan prinsip kepemimpinannya, sikap kepemimpinan kiai diantaranya tegas, sabar, Istoqomah, low profile, senang Riyadhah, tirakat dan ahli dzikir serta dermawan kepada bawahannya sedangkan prinsip kepemimpinannya yaitu kemuliaan melalui usaha bukan karena nasab dan 6 S (Sopan, Santun, Salam, Sapa, Senyum dan Sanjung). Basis dasar kekuasaan kiai terbentuk dari keluarga,pendidikan, lingkungan moderat, aktivitas kutural dan struktural organisasi kegamaan yang digelutinya.

Modal kekuasaan yang dijalankan oleh kiai berupa modal intlektual,emosional dan spritual, sedangkan Model-modelnyanya terdiri refrent power, persuasif power, power given by society, advice power, apresiatif power dan Doble conection power, dan taktik kekuasaan kiai dengan apresiasi, fasilitasi, sharing dan motivasi sedangkan media kontrolnya menggunakan forum silaturrahim bulanan dan silaturrahim mingguan bersama keluarga dekat dan bawahannya.

\section{DAFTAR PUSTAKA}

Dominica R. Lorbes. 2008. Influence, Power \& Politics in the Organisation. Organizational Behavior \& Development, 1 st Semester SY.

Fremonth E. Kast and Rosenzweig,2002.Organisasi dan Manajemen: Alih Bahasa. Jakarta: Bumi Aksara.

Gibson, Ivancevich, Donnely Jr. 2001. Organisasi Perilaku, Struktur, Proses, Jilid I Edisi Lima, Jakarta: Erlangga

Litwin \& Stringer. "Definisi Iklim Organisasi", http://jurnalsdm.blogspot.com, diakses 28 Juli 2015.

Luthan, Fred, 2002.Organizational Behavior Ninth edition, Mc. Graw- Hill, Boston.

M. Nuhrison ,2010, Peranan Pesantren dalam Mengembangkan Budaya Damai Jakarta: Balitbang Kemenag.

Martin van Bruinessen. 1994.Pesantren and Kitab Kuning: Continuity and Change in a Tradition of Religious Learning. Dalam Wolfgang Marschall ed. Texts from the Islands: Oral and Written Traditions of Indonesia and the Malay World Etnhnologica Bernensia. Berne: The University of Berne Institute Ethnology.

Owens, Robert G,1995.Organizatoinal Behavior in Education. Allyn and Bacon. Boston

Pfeffer, 1996.M. The Art to maintenance Human Resources. New York:Mc. Graw-Hill Company.

Qomar, Mujamil,2004. Pesantren dari Tarnsformasi Metodologi Menuju Demokratisasii Institusi Jakarta: Erlangga. 
Robbins, S. P. 2005. Essential of Organizational Behavior $5^{\text {th }}$. Edisi Terjemahan Halida dan Sartika. Jakarta: Erlangga.

Robbins, Stephen P. dan Timothy A. Judge,2001. Organizational Behavior. $15^{\text {th }}$ Edition. New Jersey: Pearson Boston: Pearson Edication

Robbins, Stephen,2001. Perilaku Organisasi: Terjemahan: Edisi Kedelapan: Jilid I. Jakarta: Prenlindo.

Sopiah, 2008.Prilaku Organisasi, CV. Andi Offset, Yogyakarta

Suharsaputra, Udar, 2013. Administrasi Pendidikan. Bandung :PT. Rafika Aditama

Sukamto,1999. Kepemimpinan Kiai dalam Pesantren, Jakarta: LP3ES,

Walid, 2010, Napak tilas kepemimpinan KH.Ach.Muzakky Syah, Yogyakarta: Absolut Media

Walid, 2010. Napak tilas kepemimpinan KH.Ach.Muzakky Syah, Yogyakarta : Absolut Media

William G. Scott \& Terence R. Mitchell, 1972.Organization theory: a structural and behavioral analysis Richard D. Irwin \& The Dorsey Press Publication

Yukl. Gary, 1998. Leadership in Organization (4th edition) Upper Saddle River, New York: Prentice Hall. 